\title{
Occurrence of anti-Toxoplasma gondii antibodies in meat and dairy goat herds in Rio Grande do Norte, Brazil
}

\author{
Ocorrência de anticorpos anti-Toxoplasma gondii em rebanhos caprinos de corte e leiteiros do \\ Rio Grande do Norte, Brasil
Andréa Dantas de Medeiros; Milena de Medeiros Clementino Andrade ${ }^{1,2}$; Ricardo Wagner de Almeida Vítor²; Valter Ferreira de Andrade-Neto ${ }^{1 *}$

\begin{abstract}
${ }^{1}$ Laboratory of Malaria and Toxoplasmosis Biology, Department of Microbiology and Parasitology, Biosciences Center, Federal University of Rio Grande do Norte - UFRN, Natal, RN, Brazil

${ }^{2}$ Department of Parasitology, Institute of Biological Sciences - ICB, Federal University of Minas Gerais - UFMG, Belo Horizonte, MG, Brazil
\end{abstract}

Received May 22, 2014

Accepted September 22, 2014

\begin{abstract}
Toxoplasmosis is caused by Toxoplasma gondii, which is the main causative agent of abortion in small ruminants. Goats are among the animals that are most susceptible to this protozoon, and the disease that it causes leads to significant economic losses and has implications for public health, since presence of the parasite in products of goat origin is one of the main sources of human infection. Because of the significant economic impact, there is an urgent need to study the prevalence of T. gondii infection among goats in Sertão do Cabugi, which is the largest goat-producing region in Rio Grande do Norte. In the present study, the ELISA assay was used to test 244 serum samples from nine farms, located in four different municipalities in the Sertão do Cabugi region, which is an important goat-rearing region. The results showed that the prevalence of anti-T. gondii antibodies was $47.1 \%$ and that there was a significant association between positivity and the variables of age ( $\geq 34$ months), location (Lajes, Angicos and Afonso Bezerra) and farm (all the farms). The avidity test was applied to all the 115 ELISA-positive samples to distinguish between acute and chronic infection. One hundred and three samples (89.6\%) displayed high-avidity antibodies, thus indicating that most of the animals presented chronic infection, with a consequent great impact on the development of the goat production system and a risk to human health.
\end{abstract}

Keywords: Toxoplasma gondii infection, goats, avidity ELISA, anti-T. gondii antibodies, risk factors.

\section{Resumo}

A toxoplasmose é causada pelo Toxoplasma gondii, principal agente causador de aborto em pequenos ruminantes. Os caprinos são uns dos animais mais suscetíveis a esse protozoário, levando a perdas econômicas significativas e implicaçôes para a saúde pública, uma vez que a presença do parasito em produtos de origem caprina é uma das principais fontes de infecção humana. Devido ao impacto econômico significativo torna-se urgente estudar a prevalência da infecção, pelo T. gondii, entre caprinos do Sertão do Cabugi, a maior regiáo produtora de caprinos no Rio Grande do Norte. O presente estudo utilizou o ELISA para testar 244 amostras de soro de 9 fazendas, situadas em 4 diferentes cidades na regiấo do Sertáo do Cabugi; uma importante regiáo de criaçáo de cabras. Os resultados mostraram uma prevalência de 47,1\% para anticorpos anti- $T$. gondii e uma significativa associação entre a positividade e as variáveis idade ( $\geq 34$ meses), localizaçáo (Lajes, Angicos e Afonso Bezerra e propriedade (todas as fazendas). O teste de avidez foi aplicado a todas as 115 amostras positivas pelo ELISA para discriminar entre infecção aguda e crônica. Cento e três amostras $(89,6 \%)$ apresentaram anticorpos de alta avidez; indicando que a maioria dos animais estavam em infecçáo crônica, gerando um grande impacto sobre o desenvolvimento do sistema de produçáo em cabras e um risco para a saúde humana.

Palavras-chave: Infecção por Toxoplasma gondii, caprinos, ELISA de avidez, anticorpos anti-T.gondii, fatores de risco.

\footnotetext{
*Corresponding author: Valter Ferreira Andrade-Neto, Laboratory of Malaria and Toxoplasmosis Biology, Department of Microbiology and Parasitology, Biosciences Center, Federal University of Rio Grande do Norte - UFRN, Av. Senador Salgado Filho, Campus Universitário, Lagoa Nova, CP 1524, CEP 59000-000, Natal, RN, Brasil, e-mail: aneto@cb.ufrn.br; vfan.aneto@gmail.com
} 


\section{Introduction}

Toxoplasmosis is a zoonosis that is present worldwide and is caused by Toxoplasma gondii, an obligate intracellular protozoan. It is considered to be one of the most widespread transmittable infectious diseases. The parasite that causes this disease is of considerable medical and veterinary importance because it causes abortion, fetal malformation and neonatal mortality, with significant impact on goat and sheep farming (APPLEFORD \& SMITH, 2000; PANADERO et al., 2010). Worldwide interest in raising meat and dairy goats has reached unprecedented importance, and this phenomenon is clearly apparent in Brazil. Among production animals, goats are among the ones most susceptible to T. gondii (DUBEY \& ADAMS, 1990). The economic importance of the exploitation of goats is significant in various regions around the world (DUBEUF et al., 2004; BOYAZOGLU et al., 2005). Goat herds in South America account for 3.5\% of the worldwide total population, while Brazilian herds include a total of 9,450,312 animals (1.1\% of the world total and $32.3 \%$ of South American herds). Brazil is among the leading producers of dairy goat herds (DUBEUF et al., 2004; IBGE, 2012). Goats' ability to eliminate T. gondii through their milk and the persistence of tissue cysts in goats (DUBEY, 1980) demonstrate the significance of this species in transmitting toxoplasmosis to humans (SACKS et al., 1982). Thus, when improperly prepared, the infected meat and milk of these animals is one of the most important potential sources of human toxoplasmosis (TENTER et al., 2000; CLEMENTINO et al., 2009; SANTOS et al., 2012; BEZERRA et al., 2013). Considering the high number of goat herds in northeastern Brazil and the economic losses caused by this parasite, the aims of this study were to investigate the seroprevalence of $T$. gondii among goats, along with the associated risk factors, and to identify recent and/or chronic infection by $T$. gondii in the Sertâo do Cabugi region, Rio Grande do Norte, Brazil.

\section{Materials and Methods}

\section{Study area}

The state of Rio Grande do Norte is divided into four geographic mesoregions: Agreste Potiguar, Eastern Potiguar, Central Potiguar and Western Potiguar (IDEMA, 2011). The animals used in the present study were from herds in the Central Potiguar mesoregion, which has a very hot semiarid climate, with a mean annual temperature of $27.2{ }^{\circ} \mathrm{C}$, annual relative humidity averaging $70 \%$ and caatinga vegetation. This vegetation consists of scrub plants that are adapted to the arid conditions typical of semiarid regions, with loss of foliage during the dry season (IDEMA, 2011). This study was conducted on farms belonging to the Sertâo do Cabugi Sheep and Goat Breeders Association (ACOSC), state of Rio Grande do Norte.

\section{Animals and serum}

This study was characterized as a cross-sectional study in which the total sample size to be obtained was established as 244 animals, proportionally, from nine farms. The animals were selected through non-probabilistic sampling. Blood samples from goats aged between 5 months and 7 years were collected on nine meat and dairy goat farms. The animals were tagged and identified in individual records containing the following information: animal identification number, age, breed and sex. The animals were classified into four age groups: 6-12 months $(22.1 \%), 13-$ 24 months (21.7\%), 25-33 months (15.2\%) and > 34 months (41\%). Among the goats evaluated, $88.5 \%$ were pure breed and $11.5 \%$ crossbreed (resulting from crossing different breeds). Blood collection was performed in the goat herd simultaneously with application of a questionnaire. Blood was drawn through the jugular vein using Vacutainer ${ }^{\circledR}$ vacuum blood collection tubes without sterile anticoagulants. The tubes were packed in a Styrofoam box containing gel ice packs and were taken to the Laboratory of Malaria and Toxoplasmosis Biology (LABMAT), in the Department of Microbiology and Parasitology at the Federal University of Rio Grande do Norte. The serum was separated by means of centrifugation ( $444 \mathrm{x} g$ for 5 minutes) and was stored at $-20{ }^{\circ} \mathrm{C}$ until use.

\section{Antigen}

Tachyzoites ( $T$. gondii RH 88 strain) were harvested from the peritoneum of Swiss mice that had been inoculated one week previously with $10^{3}$ or $10^{4}$ tachyzoites by means of the intraperitoneal route (i.p.). Soluble tachyzoite antigen (STAg) for ELISA was prepared by resuspending tachyzoites in phosphate buffered saline (PBS) at $\mathrm{pH} 7.2$ and sonication in ice-water, in accordance with the protocol described by Elsaid et al. (2001). After centrifugation at $4{ }^{\circ} \mathrm{C}(998 \times \mathrm{g}$ for $10 \mathrm{~min})$ the supernatant was collected and stored as aliquots at $-20^{\circ} \mathrm{C}$ until use. The protein concentration was determined in accordance with the Lowry method (LOWRY et al., 1951).

\section{ELISA assay}

ELISA was performed as described by Vitor et al. (1999) with slight modifications. Briefly, flat-bottomed 96-well polystyrene microplates were sensitized using $100 \mu \mathrm{L}$ of STAg in each well, at a concentration of $1 \mu \mathrm{g} / \mathrm{ml}$. Goat serum samples were diluted in PBS-T (Tween-20 at $0.05 \%$ in PBS at pH 7.2), at a dilution ratio of 1:100 in duplicate, and $100 \mu \mathrm{L}$ was distributed into each well, followed by incubation at $37^{\circ} \mathrm{C}$ for 45 minutes. Then, 100 $\mu \mathrm{L}$ of anti-goat $\mathrm{IgG}$ immunoglobulin labeled with peroxidase (SIGMA, product A-5420) diluted at 1:5000 in PBS-T was added to each well and incubated for 45 minutes at $37^{\circ} \mathrm{C}$. The reaction was viewed using ortho-phenylenodiamine and was stopped with $4 \mathrm{~N}-\mathrm{H}_{2} \mathrm{SO}_{4}$. The absorbance was read at $490 \mathrm{~nm}$ on a BIORAD microplate reader, model 3550. The cutoff point for ELISA was the mean absorbance of three serum samples from $T$. gondiinegative goats plus three standard deviations, tested in each plate. The mean from the serum samples tested in triplicate was divided 
by the plate cutoff point in order to determine the reactivity index (RI). Serum samples with $\mathrm{RI} \geq 1$ were considered positive.

\section{IgG avidity ELISA}

In parallel with conventional ELISA, an additional ELISA was performed to evaluate $\operatorname{IgG}$ antibody avidity in samples that had previously been subjected to conventional ELISA testing, using urea as a dissociating agent for the antigen-antibody bond. This test is an indicator of recent or chronic infection. The technique was carried out in accordance with the protocol described by Clementino et al. (2007). The microplates were sensitized as previously described. The serum samples were assayed in two duplicate series on the same plate: the samples in columns 1 to 6 on each plate were the same as those processed in columns 7 to 12. After incubation, a series of three washes was performed. In the first, one series (columns 1 to 6) was washed with PBS-T $(100 \mu \mathrm{L} /$ well) and the other (columns 7 to 12$)$ with $6 \mathrm{M}$ urea in PBS-T (100 $\mu \mathrm{l} /$ well), under stirring for 5 minutes. The remaining two washes were carried out with PBS-T $(100 \mu \mathrm{L} /$ well $)$ under stirring, also in two 5-minute cycles. Next, $100 \mu \mathrm{L}$ of conjugate was added to each well. From this point onwards, the procedure was identical to that described for conventional ELISA.

The avidity of IgG antibodies is calculated as the ratio between the mean absorbance for each serum sample obtained in wells treated with urea (AU) and the mean absorbance of untreated wells (A), expressed as a percentage: AU/A x 100 [11]. According to Suaréz-Aranda et al. (2000), avidity values $\geq 50 \%$ indicate chronic toxoplasmosis, while values $<50 \%$ suggest recent infection.

\section{Ethical approval}

This study was approved by the Ethics Committee of the Federal University of Rio Grande do Norte (UFRN), Natal, RN, Brazil (CEUA 043/2010).

\section{Statistical analysis}

A database was generated using the EpiData version 2.1 software and statistical analyses were performed using the Stata Statistical software, version $10 \mathrm{SE}$. The frequencies of $T$. gondii and low and high-avidity IgG antibodies were correlated with sex, age, breed and municipalities using the chi-square test. Univariate analysis was used to quantify the association between risk factors and infection by $T$. gondii, using logistic regression.

Potential risk factors were assessed by calculating the risk through odds ratios with 95\% confidence intervals (CI). A significance level of 0.05 was chosen.

\section{Results}

In this study, females predominated $(91.8 \%)$, since the farms produced both milk and meat for subsistence consumption and/ or for marketing in the region.

Out of the 244 goat serum samples analyzed, $47.1 \%$ (115/244) were considered reactive for Toxoplasma gondii, according to ELISA testing. Table 1 shows seropositivity according to gender, age, breed and municipalities. Evaluated proportionally, the percentage of positive males was similar to that observed for

Table 1. Distribution of serum reactivity anti-Toxoplasma gondii IgG antibodies among goats in relation to the variables of sex, age, breed, municipality and farm from the Sertão do Cabugi region of the state of Rio Grande do Norte, Brazil.

\begin{tabular}{|c|c|c|c|c|c|c|}
\hline \multirow{2}{*}{ Variable } & & \multicolumn{2}{|c|}{ ELISA assay } & \multirow{2}{*}{ Total } & \multirow{2}{*}{$\mathrm{X}^{2}$} & \multirow{2}{*}{$\mathbf{P}$} \\
\hline & & $+(\%)$ & $-(\%)$ & & & \\
\hline \multirow[t]{2}{*}{ Sex } & Male & $9(3.7)$ & $11(4.5)$ & 20 & 0.04 & 0.84 \\
\hline & Female & $106(43.4)$ & $118(48.4)$ & 224 & & \\
\hline \multirow[t]{4}{*}{ Age } & $\leq 12$ & $31(12.7)$ & $23(9.4)$ & 54 & 17.04 & 0.0007 \\
\hline & $13-24$ & $17(7)$ & $36(14.7)$ & 53 & & \\
\hline & $25-33$ & $10(4.1)$ & $27(11.1)$ & 37 & & \\
\hline & $\geq 34$ & $57(23.4)$ & 43 (17.6) & 100 & & \\
\hline \multirow[t]{2}{*}{ Breed } & Pure & $98(40.1)$ & $118(48.4)$ & 216 & 2.34 & 0.12 \\
\hline & Mixed & $17(7)$ & $11(4.5)$ & 28 & & \\
\hline \multirow[t]{4}{*}{ Municipalities } & LJ & $42(17.2)$ & $82(33.7)$ & 124 & 19.68 & 0.0002 \\
\hline & AG & $25(10.2)$ & $11(4.5)$ & 36 & & \\
\hline & PA & $19(7.8)$ & $12(4.9)$ & 31 & & \\
\hline & $\mathrm{AB}$ & $29(11.9)$ & $24(9.8)$ & 53 & & \\
\hline \multirow[t]{8}{*}{ Farms } & $\mathrm{BV}$ & $4(1.64)$ & $9(3.7)$ & 13 & 45.2 & 0.0001 \\
\hline & SG & $12(5)$ & $2(0.8)$ & 14 & & \\
\hline & DI & $14(5.7)$ & 48 (19.7) & 62 & & \\
\hline & SR1 & $12(5)$ & $23(9.4)$ & 35 & & \\
\hline & $\mathrm{BN}$ & $25(10.2)$ & $11(4.5)$ & 36 & & \\
\hline & RF & $9(3.7)$ & 7 (2.9) & 16 & & \\
\hline & $\mathrm{AF}$ & $10(4.1)$ & $5(2)$ & 15 & & \\
\hline & SR2 & $21(8.6)$ & $9(3.7)$ & 30 & & \\
\hline
\end{tabular}

\footnotetext{
The percentage is in relation to the total number of animals evaluated in this study (244 animals).
} 
the females. The results showed that the positivity rate increased with the age group $(p<0.0007)$. Regarding breed, $40.1 \%$ of the pure breed and $7 \%$ of the crossbreed goats were positive; however, from proportional analysis within the respective groups, there was no statistical difference.

Seropositivity frequency among the goats varied significantly between 11.8 and $17.2 \%$ according to the municipality $(p=0.0002)$. In relation to the farms, the results showed that there was a positive association between this variable and the presence of anti-T. gondii antibodies $(p=0.0001)$.

The IgG avidity ELISA test was conducted to determine the avidity of IgG antibodies in the serum samples from 115 positive goats. Of these, 103 samples presented high-avidity IgG antibodies (chronic infection) and 12 had IgG antibodies with low avidity (acute infection). Compared with the total number of animals studied (244), 42.2\% of them were probably in the chronic phase and $4.9 \%$ in the acute phase. Analysis on the correlation between the avidity of anti- $T$. gondii IgG antibodies and the variables of age, breed, sex and municipality using the chi-square test showed that there was a statistically significant difference in relation to sex $(p<0.05)$. Female goats had higher-avidity IgG antibodies than those of male goats. No statistical difference was found for

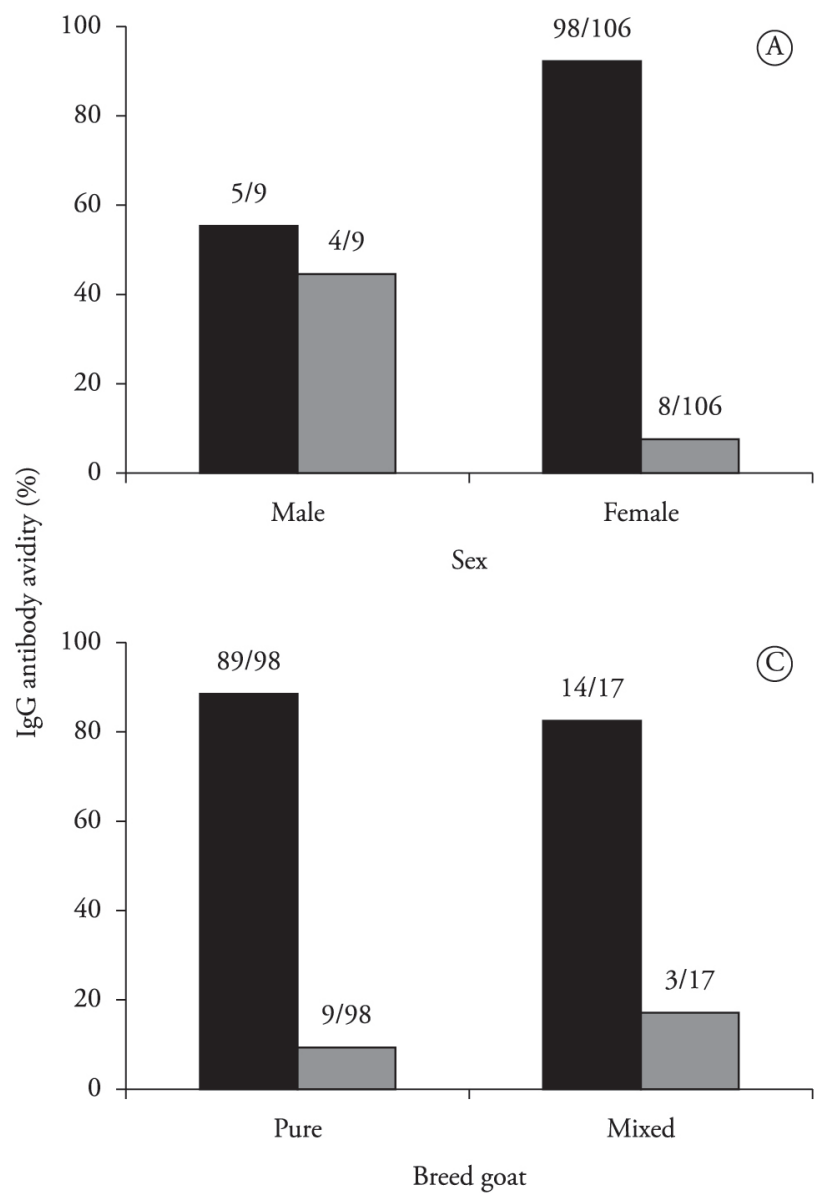

the remaining variables $(p>0.05)$. These data are summarized in Figure 1.

\section{Discussion}

Toxoplasmosis is an important worldwide zoonosis and small ruminants are a significant part of the epidemiological chain. In the light of the importance of products of goat origin as a human food source, contamination of such products by the protozoon Toxoplasma gondii when they are inadequately prepared can lead to public health problems in the form of toxoplasmosis. This infection is often neglected in developing countries, thus resulting in reproductive and economic losses among herds, particularly in rural and semi-rural areas (CAVALCANTE et al., 2008; BEZERRA et al., 2013).

This is the second study to investigate toxoplasmosis among goats in the state of Rio Grande do Norte. The first, conducted by Neto et al. (2008) in the Eastern Seridó region, found that the seroprevalence for toxoplasmosis was 30.6\%. Recently, our group observed seroprevalence of anti-T. gondii antibodies of $22.1 \%$ among sheep in the same State, and the age of the animals, presence of cats and use of unexposed water sources were risk factors for toxoplasmosis in sheep (CLEMENTINO
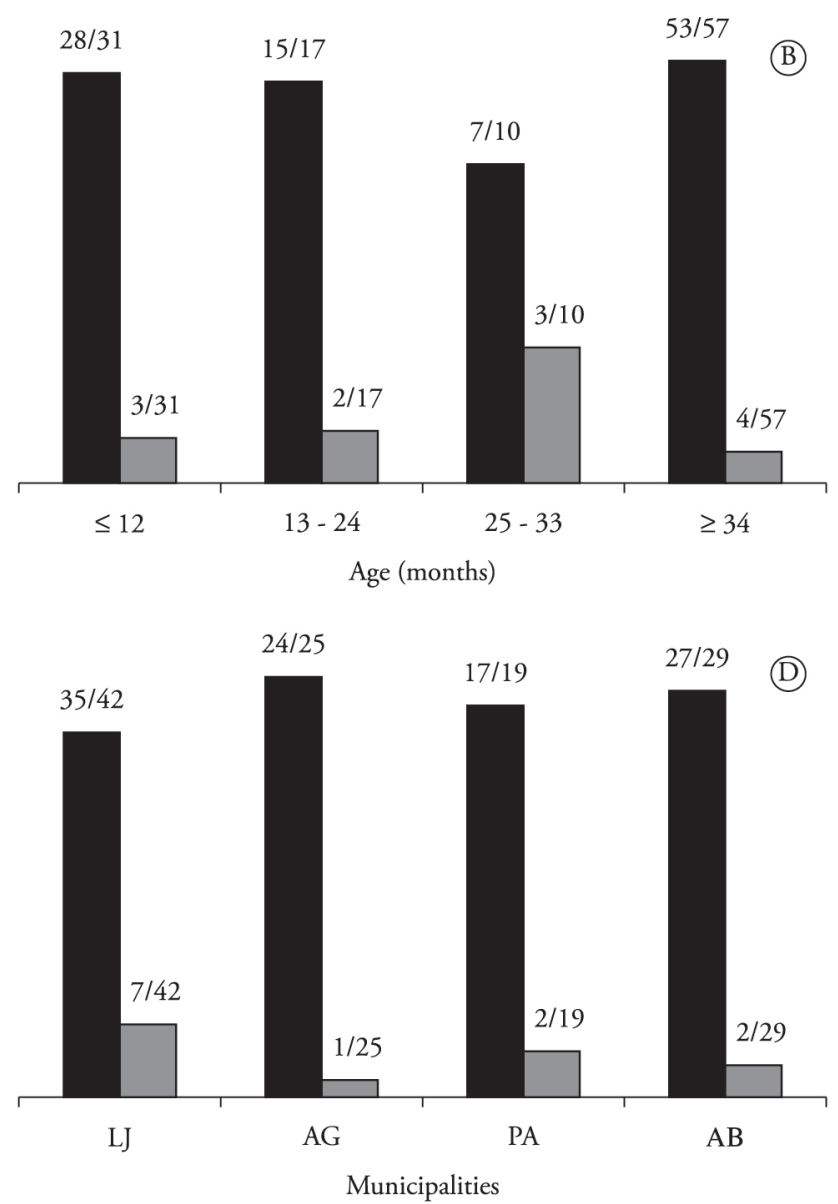

Figure 1. Avidity frequency obtained from 115 goats that were positive for Toxoplasma gondii, in relation to sex (A), age (B), goat breed (C) and municipality in the Sertão do Cabugi region (D), Rio Grande do Norte state, Brazil. Low avidity (gray bars), high avidity (black bars); numbers above the bars represent the absolute values. $\mathrm{LJ}=$ Lajes; $\mathrm{AG}=$ Angicos; $\mathrm{PA}=$ Pedro Avelino; $\mathrm{AB}=\mathrm{Afonso}$ Bezerra. 
ANDRADE et al., 2013). This value is close to those of previous observations in the same state: $29.4 \%$ and $20.7 \%$ of the sheep tested positive in the municipalities of Lajes and Mossoró, respectively (CLEMENTINO et al., 2007; SOARES et al., 2009). This finding fact is very important because sheep and goat farming is the main livestock activity in Rio Grande do Norte, and thus has a high socioeconomic impact.

Variation in seroprevalence is evident in Brazil, as demonstrated by several studies carried out in Bahia (UZÊEA et al., 2004), Ceará (CAVALCANTE et al., 2008), Minas Gerais (CARNEIRO et al., 2009), Alagoas (ANDERLINI et al., 2011), Paraíba (SANTOS et al., 2012) and Fernando de Noronha (COSTA et al., 2012), with a range from 16.4 to $81.8 \%$. The differences observed may be due to a variety of factors: sampling of animals evaluated, presence or absence of cats on farms, climatic conditions, types of management and different diagnostic techniques used.

In the present study, the seropositivity rate was unrelated to the sex of the goats. This result has been corroborated by other studies, in which it was also found that there was no significant association between sex and the presence of anti- $T$. gondii antibodies (CAVALCANTE et al., 2008; CARNEIRO et al., 2009). Other studies have suggested that females are more vulnerable to $T$. gondii than males are (UZÊEDA et al., 2004; ACICI et al., 2008; ZEWDU et al. 2013). This probably occurs as a result of possible immunosuppression related to pregnancy and lactation (UZÊEA et al., 2004), as well as the type of management, since dairy females are subject to intensive husbandry in many regions of northeastern Brazil (SILVA et al., 2003). The animals were also grouped into two categories: pure and mixed breed. In this case, there was no statistical significance regarding prevalence. This finding is corroborated by studies conducted in the state of Ceará (CAVALCANTE et al., 2008). However, this differs from the results published by Carneiro et al. (2009), who found that exploitation of pure-breed goats gave rise to twice the chance of infection, compared with undefined breeds or crossbreed goats.

With regard to age, a significant difference in reactivity was recorded among animals older than 34 months, which exhibited higher reactivity rates than younger goats, thus suggesting greater likelihood of becoming infected, since these animals will have been exposed to the etiological agent for longer time periods (CAVALCANTE et al., 2008; CARNEIRO et al., 2009; ZEWDU et al., 2013). However, our results differ from those of Uzêda et al., who did not observe any significant difference in relation to age (UZÊEDA et al., 2004).

A significant difference was recorded between the four municipalities investigated. The high percentage of $T$. gondiireactive goats in the municipalities of Lajes, Angicos and Afonso Bezerra can be explained by the resistance of oocysts in the environment, associated with a large degree of genetic diversity (RAGOZO et al., 2010). The mean annual temperature and rainfall in the municipalities analyzed, though substantially different from what is seen in locations where oocysts remain viable for over a year, also favor the development and maintenance of $T$. gondii oocysts in the environment (DUBEY \& BEATTIE, 1988). A temperature of $25^{\circ} \mathrm{C}$ is considered ideal for oocyst sporulation. It has also been reported that the proportions of $T$. gondii-positive goats are smaller in regions with lower temperatures than in those with higher temperatures (FRENKEL \& DUBEY, 1973).

High IgG avidity is a good predictive tool for defining whether acute toxoplasmosis (primary infection) occurred no less than four months previously. However, a definite diagnosis of acute toxoplasmosis cannot be made based only on low or intermediate avidity, since there is substantial inter-individual variation in maximum persistence of low avidity. This means that avidity testing is an additional tool that can be used to define the minimum time period that has elapsed since infection, in the case of elevated values (HEDMAN et al., 1989). Thus, IgG avidity was assessed among the positive animals in this study in order to diagnosis acute or chronic toxoplasmosis. Our results indicated that most of the serum samples examined displayed high-avidity antibodies, thus suggesting that most of the animals were chronically infected with T. gondii. These findings were similar to those observed in the state of Minas Gerais (CARNEIRO et al., 2009).

The variables of sex, age, breed and municipality were also analyzed with regard to the avidity of IgG antibodies. Only sex demonstrated a significant association, thus differing from the results found by Carneiro et al., who reported that there was no correlation between sex and the presence of anti-T. gondii IgG antibodies (CARNEIRO et al., 2009). Although the number of males evaluated in our study was small, we cannot rule out the possibility that the differences between male and female hormones play an important role in determining susceptibility to parasite infection. It has been reported that estrogen increases antibody production and androgens suppress both T cells and B cells, thereby modulating the immune response (DA SILVA, 1999).

With regard to location, large percentages of high-avidity antibodies were found in all municipalities, thus indicating that the animals in Sertão do Cabugi were subject to early exposure to the parasite. On the other hand, a breeding system combining extensive/semi-intensive management is common in this region and may lead to greater likelihood of contact with sporulated oocysts in pastures, among these animals. In other similar studies, the higher prevalences verified in goat herds were associated with the presence of high-density populations of cats (CAVALCANTE et al., 2008).

The frequency observed in this study confirms that this parasite has spread to the main goat-producing region of Rio Grande do Norte. This has had a great impact on the development of the goat production system and, at the same time, it imposes a burden with regard to human health, mainly in relation to consumption of unprocessed milk. There is a need to develop new strategies in order to prevent horizontal transmission to humans. The prospects for toxoplasmosis control may involve vaccine development, which has been studied by our group, based on the GRAs and SAGs proteins.

\section{Acknowledgements}

We would like to thank I. P. Figueiredo for giving us access to the farms and facilitating the collection of blood samples. This study was part of a thesis for ADM, who was a student in the Postgraduate Biological Science Program at the Federal University of Rio Grande do Norte, Brazil. The authors are grateful for the grants and/or scholarships received from the Brazilian agencies FAPERN and CNPq (grant 301837/2012-0). 


\section{References}

Acici M, Babur C, Kilic S, Hokelek M, Kurt M. Prevalence of antibodies to Toxoplasma gondii infection in humans and domestic animals in Samsun province, Turkey. Trop Anim Health Prod 2008; 40(5): 311 315. http://dx.doi.org/10.1007/s11250-007-9101-6. PMid:18509937

Anderlini GA, Mota RA, Faria EB, Cavalcanti EF, Valença RM, Pinheiro Júnior JW, et al. Occurrence and risk factors associated with infection by Toxoplasma gondii in goats in the State of Alagoas, Brazil. Rev Soc Bras Med Trop 2011; 44(2): 157-162. http://dx.doi.org/10.1590/S003786822011005000017. PMid:21503550

Appleford PJ, Smith JE. Strain and stage specific variation in Toxoplasma gondii antigens. Int J Parasitol 2000; 30(11): 1187-1191. http://dx.doi. org/10.1016/S0020-7519(00)00109-0. PMid:11027786

Bezerra MJ, Kim PC, Moraes EP, Sá SG, Albuquerque PP, Silva JG, et al. Detection of Toxoplasma gondii in the milk of naturally infected goats in the Northeast of Brazil. Transbound Emerg Dis 2013; 6: 1-3. PMid:24034351.

Boyazoglu J, Hatziminaoglou I, Morand-Fehr P. The role of the goat in society: Past, present and perspectives for the future. Small Rumin Res 2005; 60(1-2): 13-23. http://dx.doi.org/10.1016/j. smallrumres.2005.06.003.

Carneiro ACAV, Carneiro M, Gouveia AMG, Guimarães AS, Marques APR, Vilas-Boas LS, et al. Seroprevalence and risk factors of caprine toxoplasmosis in Minas Gerais, Brazil. Vet Parasitol 2009; 160(3-4): 225 229. http://dx.doi.org/10.1016/j.vetpar.2008.10.092. PMid:19091475

Cavalcante ACR, Carneiro M, Gouveia AMG, Pinheiro RR, Vitor RWA. Risk factors for infection by Toxoplasma gondii in herds of goats in Ceará, Brazil. Arq Bras Med Vet Zootec 2008; 60(1): 36-41. http:// dx.doi.org/10.1590/S0102-09352008000100006.

Clementino MM, Souza MF, Andrade VF No. Seroprevalence and Toxoplasma gondii-IgG avidity in sheep from Lajes, Brazil. Vet Parasitol 2007; 146(3-4): 199-203. http://dx.doi.org/10.1016/j. vetpar.2007.02.036. PMid:17418950

Clementino MM, Barbosa IR, Andrade VF No. Toxoplasmosis in Sheep: A Potential risk of infection among residents and farm workers in Lajes, Brazil. Open Parasitol J 2009; 3(1): 1-3. http://dx.doi.org/10.2174/18 74421400903010001.

Clementino Andrade MM, Carneiro M, Medeiros AD, Andrade V No, Vitor RWA. Seroprevalence and risk factors associated with ovine toxoplasmosis in Northeast Brazil. Parasite 2013; 20: 20. http://dx.doi. org/10.1051/parasite/2013019. PMid:23707895

Costa DG, Marvulo MF, Silva JS, Santana SC, Magalhães FJ, Filho CD, et al. Seroprevalence of Toxoplasma gondii in domestic and wild animals from the Fernando de Noronha, Brazil. J Parasitol 2012; 98(3): 679-680. http://dx.doi.org/10.1645/GE-2910.1. PMid:22150091

Da Silva JAP. Sex hormones and glucocorticoids: interactions with the immune system. Ann N Y Acad Sci 1999; 876: 102-118. http://dx.doi. org/10.1111/j.1749-6632.1999.tb07628.x. PMid:10415599

Dubeuf J-P, Morand-Fehr P, Rubino R. Situation, changes and future of goat industry around the world. Small Rumin Res 2004; 51(2): 165-173. http://dx.doi.org/10.1016/j.smallrumres.2003.08.007.

Dubey JP. Persistence of encysted Toxoplasma gondii in caprine livers and public health significance of toxoplasmosis in goats. J Am Vet Med Assoc 1980; 177(12): 1203-1207. PMid:7440321.
Dubey JP, Beattie CP. Toxoplasmosis of animal and man. Boca Raton: CRC Press; 1988.

Dubey JP, Adams DS. Prevalence of Toxoplasma gondii antibodies in dairy goats from 1982 to 1984. J Am Vet Med Assoc 1990; 196(2): 295-296. PMid:2298654.

Elsaid MM, Martins MS, Frézard F, Braga EM, Vitor RWA. Vertical toxoplasmosis in a murine model. Protection after immunization with antigens of Toxoplasma gondii incorporated into liposomes. Mem Inst Oswaldo Cruz 2001; 96(1): 99-104. http://dx.doi.org/10.1590/S007402762001000100011. PMid:11285480

Frenkel JK, Dubey JP. Effects of freezing on the viability of toxoplasma oocysts. J Parasitol 1973; 59(3): 587-588. http://dx.doi. org/10.2307/3278803. PMid:4711675

Hedman K, Lappalainen M, Seppäiä I, Mäkelä O. Recent primary toxoplasma infection indicated by a low avidity of specific IgG. $J$ Infect Dis 1989; 159(4): 736-740. http://dx.doi.org/10.1093/infdis/159.4.736. PMid:2926163

Instituto Brasileiro de Geografia e Estatística - IBGE. Censo Agropecuário [on line]. 2012. [cited 2014 Feb 26]. Available from: http://www.sidra. ibge.gov.br/

Instituto de Desenvolvimento Sustentável e Meio Ambiente - IDEMA. Anuário Estatístico [on line]. 2011. [cited 2014 Feb 26]. Available from: http://www.idema.rn.gov.br/

Lowry OH, Rosebrough NJ, Farr AL, Randall RJ. Protein measurement with the Folin phenol reagent. J Biol Chem 1951; 193(1): 265-275. PMid:14907713.

Neto JOA, Azevedo SS, Gennari SM, Funada MR, Pena HFJ, Araújo ARCP, et al. Prevalence and risk factors for anti-Toxoplasma gondii antibodies in goats of the Seridó Oriental microregion, Rio Grande do Norte state, Northeast region of Brazil. Vet Parasitol 2008; 156(3-4): 329332. http://dx.doi.org/10.1016/j.vetpar.2008.05.013. PMid:18583058

Panadero R, Painceira A, López C, Vázquez L, Paz A, Díaz P, et al. Seroprevalence of Toxoplasma gondii and Neospora caninum in wild and domestic ruminants sharing pastures in Galicia (Northwest Spain). Res Vet Sci 2010; 88(1): 111-115. http://dx.doi.org/10.1016/j.rvsc.2009.05.010 PMid:19482324

Ragozo AMA, Pena HFJ, Yai LEO, Su C, Gennari SM. Genetic diversity among Toxoplasma gondii isolates of small ruminants from Brazil: novel genotypes revealed. Vet Parasitol2010; 170(3-4): 307-312. http://dx.doi. org/10.1016/j.vetpar.2010.02.024. PMid:20236768

Sacks JJ, Roberto RR, Brooks NF. Toxoplasmosis infection associated with raw goat's milk. JAMA 1982; 248(14): 1728-1732. http://dx.doi. org/10.1001/jama.1982.03330140038029. PMid:7120593

Santos CS, Azevedo SS, Soares HS, Higino SS, Pena HF, Alves CJ, et al. Risk factors associated with Toxoplasma gondii seroprevalence in goats in the State of Paraíba, Brazil. Rev Bras Parasitol Vet 2012; 21(4): 399-404. http://dx.doi.org/10.1590/S1984-29612012005000002. PMid:23184319

Silva AV, Cunha ELP, Meireles LR, Gottschalk S, Mota RA, Langoni $\mathrm{H}$. Toxoplasmose em ovinos e caprinos: estudos soroepidemiológico em duas regiōes do Estado de Pernambuco, Brasil. Ciênc Rural 2003; 33(1): 115-119. http://dx.doi.org/10.1590/S0103-84782003000100018.

Soares HS, Ahid SMM, Bezerra ACDS, Pena HFJ, Dias RA, Gennari SM. Prevalence of anti-Toxoplasma gondii and anti-Neospora caninum antibodies in sheep from Mossoró, Rio Grande do Norte, Brazil. Vet Parasitol 2009; 160(3-4): 211-214. http://dx.doi.org/10.1016/j. vetpar.2008.10.102. PMid:19091473 
Suaréz-Aranda F, Galisteo AJ Jr, Hiramoto RM, Cardoso RPA, Meireles LR, Miguel O, et al. The prevalence and avidity of Toxoplasma gondii IgG antibodies in pigs from Brazil and Peru. Vet Parasitol 2000; 91(1-2): 23-32. http://dx.doi.org/10.1016/S0304-4017(00)00249-1. PMid: 10889357

Tenter AM, Heckeroth AR, Weiss LM. Toxoplasma gondii: from animals to humans. Int J Parasitol 2000; 30(12-13): 1217-1258. http://dx.doi. org/10.1016/S0020-7519(00)00124-7. PMid:11113252

Uzêda RS, Fernandez SY, Jesus EEV, Pinheiro AM, Ayres MCC, Spinola $S$, et al. Fatores relacionados à presença de anticorpos IgG anti-Toxoplasma gondii em caprinos leiteiros do Estado da Bahia. Rev Bras Saúde Prod Anim 2004; 5(1): 1-8.

Vitor RWA, Ferreira AM, Fux B. Antibody response in goats experimentally infected with Toxoplasma gondii. Vet Parasitol 1999; 81(3): 259-263. http://dx.doi.org/10.1016/S0304-4017(98)00251-9. PMid:10190869

Zewdu E, Agonafir A, Tessema TS, Tilahun G, Medhin G, Vitale M, et al. Seroepidemiological study of caprine toxoplasmosis in East and West Shewa Zones, Oromia Regional State, Central Ethiopia. Res Vet Sci 2013; 94(1): 43-48. http://dx.doi.org/10.1016/j.rvsc.2012.07.020. PMid:22874923 